Educational Philosophy and Theory, 2018.

\title{
School in the (im)possibility of future: Utopia and its territorialities.
}

Grinberg, Silvia y Machado Mercedes Libertad.

Cita:

Grinberg, Silvia y Machado Mercedes Libertad (2018). School in the (im)possibility of future: Utopia and its territorialities. Educational Philosophy and Theory,.

Dirección estable: https://www.aacademica.org/mercedes.machado/17 ARK: https://n2t.net/ark:/13683/pZVb/dOy 


\section{Educational Philosophy and Theory}

\section{School in the (im)possibility of future: Utopia and its territorialities}

\section{Silvia M. Grinberg \& Mercedes L. Machado}

To cite this article: Silvia M. Grinberg \& Mercedes L. Machado (2019) School in the (im)possibility of future: Utopia and its territorialities, Educational Philosophy and Theory, 51:3, 322-334, DOI: 10.1080/00131857.2018.1485014

To link to this article: https://doi.org/10.1080/00131857.2018.1485014

\section{Published online: 02 Jul 2018.}

Submit your article to this journal

凹 Article views: 56

View Crossmark data \lceil 


\title{
School in the (im)possibility of future: Utopia and its territorialities
}

\author{
Silvia M. Grinberg ${ }^{a}$ and Mercedes L. Machadob \\ ${ }^{a}$ Consejo Nacional de Investigaciones Cientificas y Tecnicas, CONICET, Buenos Aires, Argentina; ${ }^{\text {bEscuela de }}$ \\ Humanidades, Universidad Nacional de San Martin, Buenos Aires, Argentina
}

\begin{abstract}
Utopia makes itself heard as Raphael voices a critique of who we are and configures that no-where which, paradoxically, we want to reach. We look to Deleuze and Guattari when we say that that critique can be envisioned as resistance to the present. In the passage from no-where to now-here, we revisit the territories of utopia as critique of our times, as a way to approach the question of who we are and who we want to be. In our view, education still rests on the image of a future that unfolds in the encounter with others. Education and its need/potential to enable tomorrows, to invent promises that look to places of desire, spaces that take shape as heterotopias. The notion of utopia is strained at root because defined as a no-where. At school, it is bound to the potential to create new possibilities and alternatives for life in the here and now. In this article, we will grapple with the work we do in university classrooms and in educational institutions in the slums on the outskirts of the city of Buenos Aires as a gateway from which to envision and to problematize the world. From there, we will approach the voices where other possibilities are conquered and other spaces created on the basis of the unpredictable, voices rooted in education and the need for it that produce and produce themselves in the tensions of that (im)possibility. In sum, wording the world as creation of worlds.
\end{abstract}

\section{KEYWORDS}

Heteropia; Utopia; narratives of future; school (im) possibility

\section{Introduction}

Utopia-in Thomas More's book - is the name of an island; both in that book and beyond, however, it refers to a clearly defined territory that, at the same time, is hard to pinpoint in space and time. The word itself means no-place. In creating that world, More also creates the possibility of envisioning a world that could be another. At the dawn of the sixteenth century, More, through his protagonist Raphael, describes that island in great detail as he criticizes the society in which he lived. He depicts for his amazed friends an island-a place he insists he has visited-where society is just, or at least different. We would call it utopian. Unbound to that story, utopia has become part and parcel of our being in the world, of our academic language and our contemporary life. Utopia became the desirable that is also unreachable. The promise of a fairer society worth fighting for, but whose real possibility of existence is not clear. If, for Raphael, utopia was proof of the just, in our times in has become the Janus-faced image of the desirable that at the same time confronts us with the 
impossible. It is in that tension that utopia, at once a moral obligation and a compass, guides us. It is a horizon of struggle for a social ideal, a struggle that, in current times, involves the possibility of future itself. It is a struggle for who we are but also for what we want to become. In that context, in this article we attempt, as a sort of experiment, to tension the idea idea of utopia through the stories of schooling and education told by young people who live in slums in the Metropolitan Region of Buenos Aires. Those stories voice in narrative form our being in the world as desires and fears, as ways of becoming other.

In the field of education, the notion of utopia has had great influence; it has become the way of expressing the directionality of modern schooling. Utopia (Freire, 2003) guides what education should contribute; education's moral obligation (Sirvent, 1999) that, in many cases, has become its normativity (Butler, 2015). As Lyotard (1984) has pointed out, the crisis of meta-narratives has confronted us in many different ways with the fact that'the narrative function is losing it functors, its great hero, its great dangers, its great voyages; its great goal' (xxiv) and, at the same time, this process has critical effects on 'two principal function[s], the research and the transmission of the acquired... With respect to the first function, genetics provides an example that is accessible to the layman: it owes its theoretical paradigm to cybernetics. Many other examples could be cited. As for the second function, it is common knowledge that the miniaturization and commercialization of machines is already changing the way in which learning is acquired, classified, made available, and exploited'(p. 4). In this article written decades after Lyotard's text on the postmodern condition of knowledge and, we can say here, of its transmission, we venture some notions for an education that, without falling into normativity or constructing heroes, envisions a future, a possibility of tangling lines for a utopia beyond the informational commodities that pervade knowledge societies.

That question is particularly pertinent in the anthropocene age, when human activity has become global and 'the dominant cause of most contemporary environmental change' (Lewis \& Maslin, 2015, p. 171), more specifically, catastrophe, damage, and threat to life itself (Cole, Dolphijn, \& Bradley, 2016). It is in that framework that we propose re-examining the notion of utopia as mode of straining possible places for education. In so doing, we understand that education, by definition, requires a promise, a narrative that captivates and is captivated by the many hopes that a society has for itself and that it needs to have for new generations, a promise to become 'someone' (Arendt, 1996). In very different ways, that promise is renewed in each classroom, in each encounter between the one who teaches and the one who learns. Without that promise, it would be very unlikely that that encounter even take place. Foregoing it would mean not only selling off the future but also the present.

From the becoming someone perspective, we propose that the possibility of envisioning other places - not one ideal no place - might act as a whisper of desire and as critique of the present not by summoning a no-where but by thinking in the now-here (Deleuze \& Guattari, 2003). In that shift, the notion of utopia comes upon the counter-sites of heterotopia. In Foucault's words (Foucault, 1984):

'I believe that between utopias and these quite other sites, these heterotopias, there might be a sort of mixed, joint experience, which would be the mirror. The mirror is, after all, a utopia, since it is a placeless place. In the mirror, I see myself there where I am not, in an unreal, virtual space that opens up behind the surface... But it is also a heterotopia insofar as the mirror does exist in reality, where it exerts a sort of counteraction on the position that I occupy... I come back toward myself; I begin again to direct my eyes toward myself and to reconstitute myself there where I am.' (p. 3)

It is in that framework that, through the stories of young students in the slums, we intend to find some lines of thought on the basis of which to envision the task of educating as a sort of counteraction effect that allows us to (re)construct in the now-here a promise of schooling. After all, as we will discuss below, it is in the now-here that young people dream and where prudence becomes the key to being able to keep dreaming regardless of impossible futures that deny any chance of thinking, doing, in sum, of insisting on proceeding. It is on that cusp that it seems possible to imagine future in the real space and to find alternatives to (re)constitute from the place where one is. 
What we hope to do through these narratives is not to describe the way these young people envision their schooling, but rather to test out possible ways to grapple with a conceivable promise for education in the anthropocene age. To that end, we look to narratives produced by students at secondary schools located in contexts of extreme urban poverty in Greater Buenos Aires as part of different research practices underway since 2006 . We mainly look to artwork produced by the students and some conversations we had with them from 2014 to 2016. The value of the exercise we propose here is twofold. First, because the slums are the key spaces where the future often seems denied in a present steeped in degradation (the slums as image of catastrophe (Davis, 2010; Aranbindoo, 2011). Second, because it is precisely there that, in young students' words, we come upon other ways to assemble both the possibility of future and its becoming in the present.

Envisioned as political fiction, Utopia enables reading, grappling with, and criticizing an era that appears to be inaudible or unspeakable. The stories of these young people as we understand them could be seen as an arrow, a line of thought, that, when shot, enables another way of thinking (Deleuze, 1986). The challenge lies in understanding the course of those arrows as lines that strain the promises that we make to ourselves and to those who come into the world after us, mostly the promises that guide daily life in schools. The ways the students talk and think about education take the shape of conquest of other possibilities, of potential spaces of creation-and that is where we will procure ways to make promises beyond normativity. These stories are rooted in the present time, in the now-here, and it is in and from school that they generate tensions, heighten strains, to produce images that open up and destabilize the future (Rose, 2007). How they construct the possibility of and the desire for future in their stories is, in our view, precisely where the keys to envisioning and delineating some promise for education today lies. A promise that both escapes the inevitability of a disenchanted future and articulates the future not in a no-place but in other places. Even though the world and the words in this article are told in the now-here of the Buenos Aires slums, we believe that they teach us ways to conquest the possibility of future itself in the no-where of our globalized world-and that is crucial to this article.

We have organized this text on the basis of an understanding of the stories of these young people as arrows. Thus understood, the stories, along with the notion of heterotopia, can help us to conceive and debate a possible promise for education in these times. Through the stories, we understand that the very idea of future is what must be conquered. In that framework, we propose that wording the world as creation of worlds is an instance key to that conquest, one that finds in education, and especially in schools space, a critical place.

\section{Utopia as critique of who we are in the now-here}

Space and time are not mutually exclusive in More's utopia, an island constituted in a tension where the materiality of its existence as project and as territory is, from our point of view, not the crux of the author's tale. Utopia can be at once, without clear distinctions, what is to come and what is to be procured; it can be envisioned as a 'territory-idea,' a seed that germinates in a distant place/time, something in the making, always-already in process. Utopia drawn in the tension of its definition as no-where can be conceived as that place/time in between the no-where and the now-here. In that framework, following Deleuze and Guattari (2003), utopia today might be understood as critique, as resistance to the present. In the passage from no-where to now-here, we revisit the territories of utopia as critique of our times, as a way to approach the question of who we are and who we want to be. It is, in our view, key that a critique understood in those terms permeate the experience of thought and education, a critique that, following Bradley, could offer lines for a geophilosphy of education insofar as the possibility of education in and of itself still rests on the image of a future that unfolds on a daily basis in the encounter with others. If, as Deleuze and Guattari point out, 'Thinking is neither a line drawn between subject and object nor a revolving of one around the other. Rather, thinking takes place in the relationship of territory and the earth' (p. 85), we propose that educational promises could operate 
as 'movements of deterritorialization inseparable from territories that open onto an elsewhere' (p. 86), invention of new possibilities of life as well as of other worlds. In the twenty-first century, that promise becomes pressing because critical, as eventement.

In this framework, Raphael's definition of the island-he speaks of utopia as a'no-where'-is provocative. His terms undermine the existence-nonexistence binary, and multiply it. Even the Greek word Nusquama, 'nowhere,' suggests that tension. How can a place have no place? How can a space have no space? The definition of this territory, it would seem, has more to do with the multiple than with the dichotomous. Exploring the notion of utopia, then, becomes an exercise of grappling with education in times when the resistance of the present (Deleuze \& Guattari, 2003) demands destabilizing the inevitability of a future that comes before us as catastrophe (Rose, 2007). We situate ourselves well outside dichotomies, beyond the iron borders between what is and what is not. The word utopia thus comes to refer to creation, invention; it names something that did not previously exist as such and that appears in Raphael's tale as a way to show that the problems of the present (his/ our present) can be worked out in other ways. At his friends' urgings, Raphael says, 'I do not wonder [...] that it appears [impossible] to you, since you have no notion, or at least no right one, of such a constitution [...]' (More, 1989, p. 81). Utopia is born in Raphael's word and story, and he leaves the island to recount it, to show that there might be other ways. That no-where is, for Raphael, proof of that possible something else.

It is in that framework that we posit as a hypothesis that the stories produced by the young students in the slum provoke and evoke other lines (spatial and temporal) that might help shape a geophilosophy of education in the present. It is in that place where, as adults, we may be surprised by the whisper (Arendt, 1996), of young people who insist on dreaming, desiring, and creating future, fully knowing the threats they face. We follow here Foucault's idea of heterotopia, the notion that'a society, as its history unfolds, can make an existing heterotopia function in a very different fashion; for each heterotopia has a precise and determined function within a society and the same heterotopia can, according to the synchrony of the culture in which it occurs, have one function or another' (1984, p. 5). It is, then, from that place that is many places that we grapple with education and our ability to explore those territories.

If we understand utopia to be that which has no place, we can return to the notion of heterotopia (Foucault, 1984) to explore territories of desire that adopt varied and variable forms; other places that resist the present by insisting on the possibility of delineating multiple'heres' in the here. At stake is not no-where, but the here in the here. Now-here as mental landscape, geography of resistance between the environment and the plane of immanence, as what Deleuze and Guattari (2003) might call contours of a geophilosophy.

It is in these terms that we understand the notion of utopia as critique of who we are, a narrative that is at once creation and critique of the times. A political fiction that envisions and grapples with its present time, reflects on its own 'real' and, in so doing, reignites its historical charge. 'Utopia is what links philosophy with its own epoch [...] It is with utopia that philosophy becomes political, and takes the criticism of its own times to its highest point. Utopia does not split off from infinite movement: etymologically it stands for absolute deterritorization but always at the critical point at which it is connected with the present relative milieu [...]' (Deleuze \& Guattari, 2003, pp. 99, 100). It is in the nowhere that the possibility of a critique of who we are, and the possibility of imagining futures-insofar as other places - takes shape. The utopia 'fiction,' like philosophy, erupts as creation of new worlds, as reflection and critique of the present time. It is in the interstices of that creation in and of these times that contemporary education dwells.

Destabilizing the present, resisting it, is the alternative that opens up before what is to come. Indicating their words and worlds, students, in introducing themselves, say the words'I want to be' as soon as they have said the words 'I am,' in an oblique critique of the present that devises the place of education in the conquest of the future. 


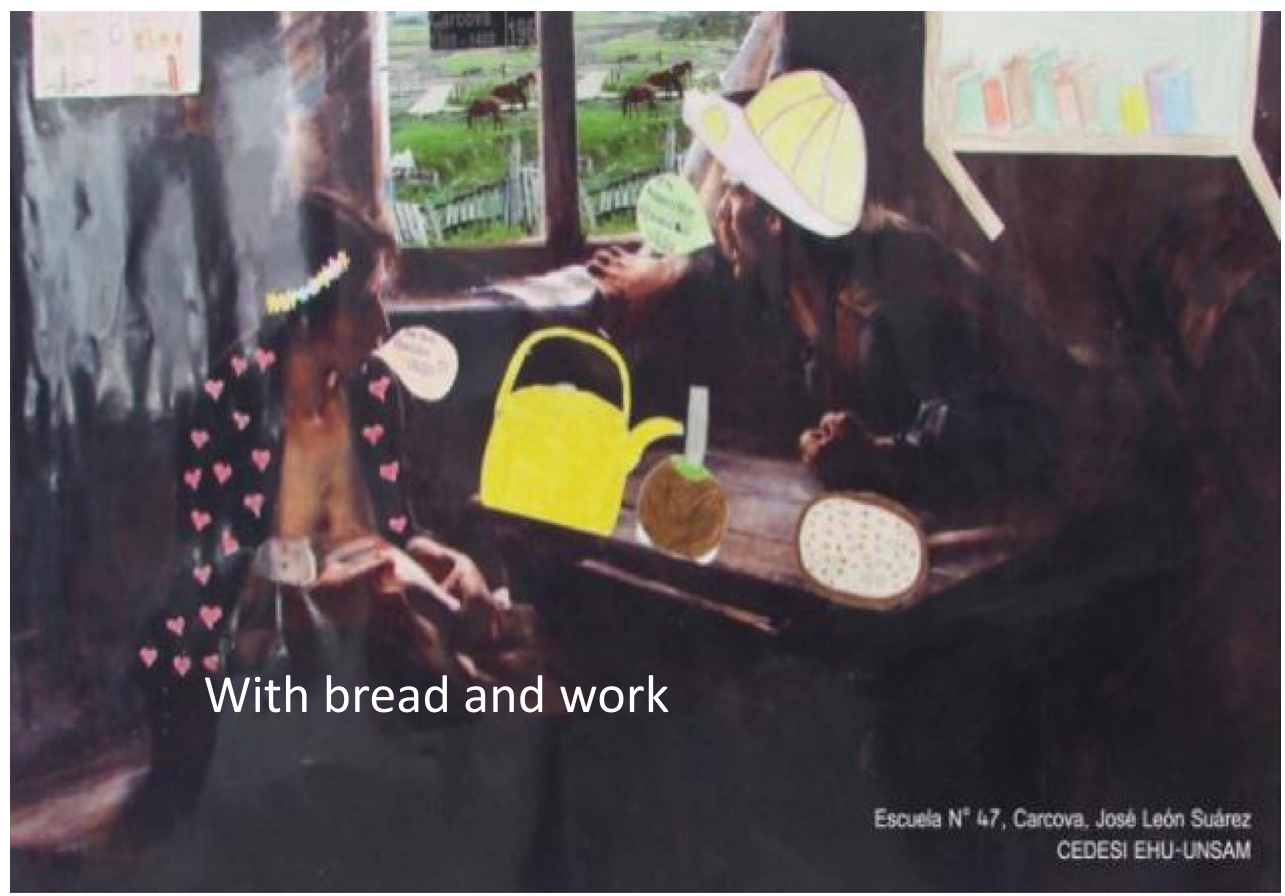

If for Raphael, at the very beginning of the sixteen century, utopia is proof of the nonsense of politics that leads subjects to break the law, the options for those who, in the twenty-first century, are left to their own devices (Grinberg, 2011) continue to heighten the tensions part and parcel of reality. The injustice is even greater because it has the power of law; it is 'legalized injustice' ('what else is to be concluded from this but that you first make thieves and then punish them?" (p. 28) condemns Raphael). What we come across, in the twenty-first century, is a very similar form of legal cruelty. As a critique of these times, the following images produced by the students simultaneously interrogate the present and injustice, and voice desire for future.

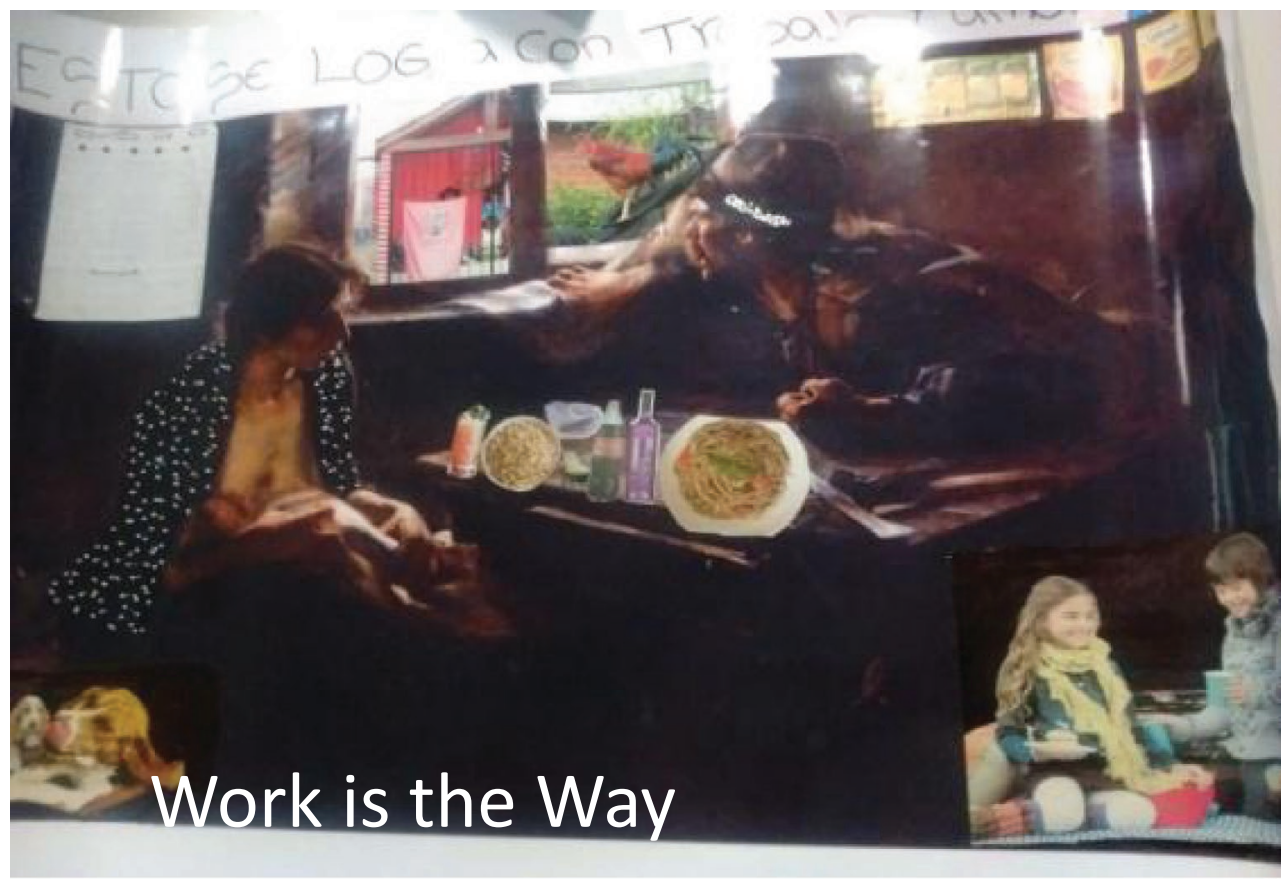


Students produced the works as interventions on a painting from the late nineteenth century entitled 'Sin Pan y sin trabajo'1 [No Bread and No Work]. One of the paintings produced by the students is re-named 'Se logra con trabajo' [Work is the Way]: condemnation and desire at once; critique of a present and affirmation of a future. One image shows a table full of food; another shows the following dialog alongside a great many books: 'What are you thinking about, old man?' asks the female figure; 'About our poverty,' answers a clearly angry male figure. Expression of thought on these times and political statements ('Work is the Way'). Both utterances compose the scene in paintings where the critique of who we are finds places to be reached (no longer no-where) that enable ways of thinking the present and articulating alternatives for the future.

\section{School, the critique and the (im)possibility of future}

The typical images of young people who live in slums are not that different from the ones who are the object of Raphael's discussion and anger. ${ }^{2}$ Far from that image that the protagonist of Moro's book describes and critiques, we suggest that two questions take shape simultaneously: while 'desire always remains in close touch with the conditions of objective existence; it embraces them and follows them, shifts when they shift, and does not outlive them...' (Deleuze \& Guattari, 1983, p. 27), the construction of the future ensues as the result of a contingency, a need born of those conditions.

In recent decades, a great deal has been written about education and its inability to generate spaces where young people can think/plan/dream the future in general and their own futures in particular. Many of those texts place emphasis on the indifference and apathy, the lack of enthusiasm and future vision, deemed characteristic of 'millennials.' Education, especially in slums, is also charged with being a place empty or emptied of meaning, a place riddled with crisis and disenchantment (Saez, 2015). Yet, that is the milieu where we come across other ways of envisioning futures, ones where education plays a central role, sometimes as escape/refuge, but always as promise of future.

The possibility and specificity of education continues to dwell in the image of future displayed and deployed in the classroom every day. Freire (2003) states that the opportunity of schooling lies in the radicalness of the experience of the human as being in the making-understanding and knowing ourselves to be incomplete is, in a sense, what enables education: the being that knows itself to be unfinished incessantly searches. Our presence in the world is not that of simply being, but that of those looking for something. For that reason, it is impossible to look for or to educate without hoping to get somewhere, though where that is may, as we argue here, be diverse and nuanced, embedded in multiple times and places. Freire speaks of education as a political act that provides access to heritage, archive, memory, to the knowledge constructed thus far, what Arendt would call the whisper. Access to the word, to concepts, to the archive: wording the world as creation of worlds - the pedagogy of the concept (Deleuze \& Guattari, 2003; Peters, 2004).

A pedagogy of concepts that, we suggest, could find in the now-here of the slum's educational space and in the storytelling that takes place in it other words with which to build other horizon, that is, not only to imagine the future but also to think the present. Word, desire, place, and time coincide; they intersect in the fabric of the educational task where, in the now-here, that whispered word is heard. That is where it is possible to imagine other worlds, to construct others meanings. Hence, if it is impossible to conceive of school without horizon, it is equally impossible to place school outside that tension. And that is likely the place of utopia in school: it does not exist but for the tension between condemnation and rejection of an often-intolerable present and announcement of a future to be created, to be constructed politically, esthetically, and ethically. Imagining what is to come in/from the present means assembling a composite future (Augé, 2012). Something of that makes itself felt in the following words that we believe might act as an arrow that unleashes the activity of thinking (Deleuze, 1986).

Education, prudence, and the act of desiring in the muck of history

[...] About what I want to be? What I want to have? Yes, I think about it often. I think and dream about it. But it's something that doesn't... Sometimes I dream and fly away. But not really. I may dream about it or think about it, but until I finish high school I can't really have a goal like having a house or a nice future. My goal for now is finishing 
school. Once I have, I'll be able to say that I've taken a load off my chest-it'll be a relief. Once l've done that, l'll be able to think... about a house, I don't know, getting a job. Being able to support myself, maybe. I don't know, a lot has to happen first. (Female student, 18 years old)

Though this young girl dreams, she also, in her endless prudence, narrates ways of thinking that, in the geography of the present, in the now-here, build bridges for desiring and becoming other. Returning to Deleuze and Guattari, 'geography is not confined to providing historical form with a substance and variable places. It is not merely physical and human but mental, like a landscape', (2003, p. 96). It is by forming part, being produced in a determined landscape, that the power of those words and their ability to be grasped lies. 'I fly away' does not refer to a place or to a no-where; she dreams about a lot of different places to be reached. Thinking, dreaming - that experimenting is what makes it possible to become, as Deleuze and Guattari would say, strangers to one's self.

The future for this student implies both that which she wants to be and knowing where she is while she dreams. That's why she comes back, turns around, and says 'but not really.' She explains that she thinks and dreams about the future a lot, that she sometimes even 'flies away' — which epitomizes the sensation of not thinking about that future that seems (im)possible to her. And that is why 'not flying away' means coming back to her present, like thinking about poverty in the painting: the goal is to finish high school to then be able to think about what comes next. The young woman is not only aware of the (im)possibilities of living and studying in the slums, but also of how hard it is to skip steps, of how useless and exhausting it is to 'fly away' too much and then come back to reality. Thinking and dreaming in the geography of an epoch, her epoch, and of a territory, her territory. Fly away, but just a little; experience and experiment with the multiple others while also registering her now-here.

High school became a prerequisite, and graduating means being able to think about a others futures; the goal is to finish, to get there. It is not a no-where to go to, to make one's way to, while dreaming about a place that might be many places. Envisioned as goal, high school is what facilitates more thinking and dreaming; it is a relief, an accomplishment, what lets you keep flying away. Flying away is also the opportunity to carry on, to continue. It is not a question of what lies beyond, but what is right at hand or even closer. The desire for a house, a job, and a whole lot of 'I don't knows' that also form part of the scene in the painting. A lot of things have yet to happen - not catastrophe but becoming, unfolding in time, enactment of a state of things. This is a hope different from the hope upheld in self-help discourses where self-management is the way to achieve goals. The act of thinking the future is, here, a conquest in and of itself, because these young people understand that they dream while they live in a slum.

Thinking and dreaming as experimenting with alternatives capable of destabilizing the future announced for slums and for those who live in them. It is a prudence born of being in the now-here. 'Sometimes I dream and fly away. But not really.'Therein lies the possibility of experimentation. Deleuze and Guattari return prudence, which harks back to Greek philosophy, in very appealing terms in their Anti-Oedipus. The concept is, according to Anotenelli, 'little studied [...] [but] interesting for a number reasons [...] [it entails] the call to experiment instead of to interpret; the need to follow certain rules of prudence in order to avoid failure in the experimentation' $(2013$, p. 3).

The prudence embodied in the young woman's words, like those of so many others we come upon every day, can be understood as 'the art of the dosage': 'because outcomes cannot be known or predicted in advance, experimentation requires patience and prudence, as certain combinations may be destructive to the experimenter and to others' (Baugh, 2010, p. 94). Therein lies prudence's wisdom as art linked to dosage that favors a fine file over a blunt hammer. Prudence is the art of weighing and measuring each and every word; the prudent ones are those who know how far they have come and how far they have to go-and how far they can go without losing touch with reality, without falling into illusion. The prudence expressed by the young woman - fly away, but just a little-establishes a goal and opens up a possibility. 'I fly away, but not really [...] I don't know, a lot has to happen first' means having your feet on the ground, being aware of the obstacles.

Dreaming and being prudent is one of the modalities of this type of conquest, a map that draws lines, signaling combinations and distinctions. 'No longer are there acts to explain, dreams or phantasies to 
interpret, childhood memories to recall, words to make signify; instead, there are colors and sounds, becomings and intensities' (Deleuze \& Guattari, 2005, p. 162).

Stories always have a number of meanings. What concerns us here is how the way the story is told establishes what is to come in the now-here-mainly, in a way beyond the grips of pessimist rhetorics, but also of self-help and self-management rhetorics that uphold the self as creator of fates outside history.

Vision of the future is not mere defense or accusation, but need. It implies plots with all sorts of lines (including lines of disenchantment) that are provocative and can be helpful to grappling with the political meanings of notions of nihilism, disenchantment, and utopia in these times. Thus, in prudently laying out other futures, young people fly way from pessimist images that sentence them to a present eternal and closed in on itself. In that, they do what Raphael did with the island, but prudently in the now-here rather than in his no-where. Dreaming, flying away, thinking are born of need, and they never stray far from it. The fatigue part and parcel of life, of experience, of living are a key part of the plot of a life that dreams prudently, and therein lie the (im)possibilities of schooling and of narratives of the future.

Nihilism, which may seem inevitable in times of geo-trauma (Cole et al., 2016), takes on provocative nuances in the words of that young woman and in the paintings; it takes the shape of an act of thinking that dares to be spoken. 'I think about our poverty, old man' followed immediately by the affirmation 'with bread and with work.' As Augé (2012) and Bloch (2004) point out, the category of nothing is as utopian as the category of everything, and the power of both lies in the fact that they have in no way been determined; envisioning the future and its possible conquests can be understood, in these urban spaces, as the opening of the (im)possible, the construction of the utopias of our times. And that is precisely where the stories of the future in schools in slums constitute both a political response to the denial of what is to come and resistance to the present.

At school, the task of making the impossible tomorrow possible, the conquest of those times/places, is central. Along those lines, one of the most striking features of the words of that student is a sort of stark realism that rests on awareness that tomorrow is constructed with what we have today, and that that today is riddled with impossibilities. These young people envisage a murky path-that, rather than a space of illusion, is where they stand as they plan, build, and conquer.

That is why, in these stories, the use of the conditional is so common. Like the utopian alphabet with its own set of words, tenses, and pronouns, what the young people have to say about education has its particularities. They use the conditional ('would hope to reach"would hope to get to be'). There is probably no verb tense capable of capturing the (im)possibilities of that dreaming of the future in slums. That does not mean, though, the denial of the future or the absence of desire, it does not mean laziness or lack of ambition, let alone accepting the present which, in the paintings reproduced above, is cause for concern and object of thought. The conditional tense, looking to Bahbha (2002) evidences the conditions in which desire happens. Thinking of maybe not making it entails a tension that takes shape in a multiple plot. It is cause for frustration, disenchantment, irritation, fatigue, but also the urgent need to open up other (im)possibilities. That means neither a romantic reading of these narratives of the future nor conformism or resignation. The unresolved potential of these young people's childhood, expressed in the phrase 'would hope to get to be,' becomes present affirmation of future desire.

These stories re-open the possibility that enables the use of the conditional. A conditional that also erupts in and enables the here and now: 'I would like to keep studying' is the engine that makes that possible. That conditional comes across in all the 'buts' indicative of (im)possibilities, but the terms are not pure or homogenous. The use of 'but' refers to both the possibility of having and the difficulty of finding.

Future desire rushes back in, though-truth to tell-it never left in the first place. It is key to heed the pace of the stories, the pauses and backs and forths, the 'buts' and 'alsos', the use of the conditional. The 'I would like' captures many of the (im)possibilities of a neighborhood but also of an epoch. The conditional is the voice of desire in a setting, in an environment; it is its contingency. The young people describe their desire to keep studying, their struggle to find something that strikes their fancy, that stirs their passion. Perhaps many young people, wherever they live, experience something similar. The 
difference lies in the conditions, the environment, the urgency of a place where time is scarce because no mistake will be forgiven.

In these schools, present and future are like a stone in a shoe, a constant reminder of pain and irritation before the conditions of existence. At the same time, the words 'present' and 'future' are uttered along with the words 'I don't know...' and 'nothing.' If taken out of context, those words can be read as lack of resilience, desire, optimism, plans for the future, hope, willpower, determination, constancy, impulse, etc., that is, as pessimism, disenchantment, and/or disinterest. What they really constitute, though, is other modes of desiring, of experimenting, of taking root in the present and of envisaging what is to come, modes not without tensions, knots, and juxtapositions, modes that do not imply 'romanticization.' And that is the territory of heteropia: 'The heterotopia is capable of juxtaposing in a single real place several spaces, several sites that are in themselves incompatible' (Foucault, 1984, p. 6).

As Magris shows (Magris, 2001), the notion of disenchantment suggests the vision of one who has seen too much; a young life overrun with traumatic experiences led by a person melancholy because aware that the world can, at times, be so enchanting. Disenchantment is an oxymoron, Magris points out, a contradiction that the intellect cannot work through: it at once signals the impossibility of enchantment, and suggests, in its voice and tone, that — despite everything-enchantment exists and might reappear when least expected. Thus, 'a voice says that life has no meaning, but its deep timbre is the echo of that meaning' (Magris, 2001, p. 2). The disenchantment that runs through the stories of the future told by young people at this school amends utopia and reinforces its basic component: hope. That hope is projected onto the future to reconcile the subject with his or her now-here. Disenchantment is, then, an ironic and melancholy, a seasoned, form of hope. It is a way of being in the world, of thinking, of dreaming futures, of conquering and delineating its territories.

That ironic, melancholic, and seasoned form of hope that is disenchantment, Bloch explains (2004), is the life of all people, a life that 'find itself daydreaming; part of those daydreams is a just banal escape... but another part is incitement, refusal to make do with the existing dreadfulness, that is, refusal to give up. In the core of that other part, which can be transmitted, is hope' (p. 2). Hope is 'the anti-effect of waiting in the face of fear and dread. It is, for that reason, the most human of all movements of the spirit, one only accessible to men and yet tied to the widest and most lucid of horizons' (p. 55). Thus, as Bloch shows, the one who aspires to something is always daydreaming, looking to the future, a future that holds the dreaded and the hoped for. The daydream projects its images onto the future, always heading in the same direction, aiming at that which seems possible.

The complexity of these young people's stories, of their plots, lies in dichotomous readings that waver between romantic optimism and fatalist nihilism. Living in the present and not daring to deliberately grapple with or envision the future would not be strange in these times. 'I don't think about that, I live in the present-what do I know?' are words heard time and again at the school. As Augé points out (2012), art, culture, and education play a crucial role in summoning the future, both immediate and remote. Otherwise, life loses interest, and consciousness of our own death would do way with any possible delight in living.

It is before the fatigue and despair that the experience of living and learning in these contexts implies that the question of the place of transmission must be, and can be, rethought. It might seem that the experience of these contexts would, in and of itself, make schooling impossible. At times, thinking, desiring, feeling is only bearable if unspoken; the future, in those cases, is located at the cusp of the thinkable, of the speakable. It turns disturbing, upsetting, and keeps quiet. It becomes silence. But the possibility of allowing another word to be uttered is precisely what makes resisting the present feasible. Future stories at school resist, they defend utopia and disenchantment as way to approach and conquer territories. Utopia does not, then, imply naive or optimistic affirmation of an ideal future, but rather projection from a present that takes shape in the tension of disenchantment and uncertainty, when topos becomes an array of places. 


\section{By way of a corollary: on utopias and heterotopias}

There are also, probably in every culture, in every civilization, real places- $[. .$.$] which are something like coun-$ ter-sites, a kind of effectively enacted utopia [...]. Places of this kind are outside of all places, even though it may be possible to indicate their location in reality. [...] I shall call them, by way of contrast to utopias, heterotopias. (Foucault, 1984, pp. 3, 4)

As we pointed out at the beginning of this article, the very term anthropocene names an age marked by the terrors of imperial and industrial destruction (Tsing, 2018); slums are a part of that scene where, since Moore's colonial times, the effects of industrialization have included the relentless expulsion of the population and the subsequent creation of new frontiers not only in the countryside but also in cities (Tsing, 2017). As Haraway (2015) suggests, the 'outrage called anthropocene entails, centrally, the destruction of places and times of refuge for people and other critters"(p. 160), and slums are the double expression of that loss of place and construction of new refuge. ${ }^{3}$ Moore, then, addresses what we now understand to be the incipient effects of that industrialization. In the discussion in the opening pages, Raphael gets angry at the relentlessness of the present according to his friends; his description of Utopia establishes the coordinates of other possible and plausible modes of sociability. The current anthropocene age, though, not only strains our present but also undermines the very possibility of future. It is in that context that Tsing (2018) states, or rather replies, "I don't want to "salvage" the Anthropocene (or capitalism) in the positive sense of salvage; instead, I want to protect patches of more-than human livability.' (p. 73) It is in that search that Tsing has suggested the idea of noticing-and that is what we have attempted to do here. In these young people's stories, we notice others ways to think and build future in the muck of history, other geographies of thoughts. We have proposed an experiment at the very core of a geo-trauma. It is in that framework that we look to Cole et al., (2016) when they ask'how does the philosopher form a provisional friendship with polluted territory and affirm the becoming of mutation?' Our exercise dwells on the provisional nature of the alternatives, on the multiple ways from and through which young people think and envision themselves in slums. What we have attempted to do, then, is to relocate the question of utopia through the narratives and desires of young people who live in these neighborhoods. And we have done that because we believe that those narratives and desires might act as 'lessons' to devise a critique of who we are and who we want to be in a setting where catastrophe seems to besiege the future; we believe they might open up possible ways of returning to utopia in order to revisit the question of education in these times.

What students see in school is a space/time that enables grappling with and envisioning the future. Knowing that there is no guarantee, no sure way, they persist rather than give up. But in this milieu the nineteenth-century utopias of progress are unsustainable, and the future takes the shape of heterotopias built in the present. Hoping for the future at school becomes key insofar as it implies'a commitment between the "teacher" and the "student," an encounter with an other, a meeting of two forces, one that searches and one that guides. Without that encounter, without that possibility of transmission, past and memory, but also future, are put on hold' (Grinberg, 2008, p. 315). That is where future must be conquered and destabilized, not only by what is to come but also by that present time that we are being: 'acting against time, and thus on time, in favor (I hope) of a time to come' (Deleuze \& Guattari, 2003, p. 112 ) is the task of thinking and of the philosophy of education. The challenge, then, is a question that pertains to the act of writing and to the writer, to seeing and hearing, proposing from within language a new language, a foreign language (Deleuze, 1996). What we come across, then, is no longer a no-where that would make the future impossible, but rather other places, modes of desiring that ensue in our time and in the muck of history. A territorial thinking that Peters (2004) ties to philosophy and that becomes an exercise key to conceiving a geophilosophy of education. Today more than ever, a geophilosophy of education means returning to the muck. After Fukushima, 'the land of hope' has-as Cole, Dolphin and Bradley point out (2016) - metamorphosed into 'the hope of land.' What we have found is modes of that hope that ensue as modulation of a scene that, unlike the one in Fukushima, does not express collapse. Modes that show how, in a life's daily life, hope is put on hold and future takes the shape of 
place to conquer: the hope of land becomes the hope for future itself- - a future that understands itself to be threatened and, hence, must be handled with prudence.

As Augé (2012) says, the concept of utopia has been unduly narrowed; abstract and arbitrary, it has been restricted to the political. The challenge becomes heeding what is actually happening rather than dwelling on what we are losing over the course of our lives, yearning for not only the past but also, somehow, for what is to come. The word utopia, in its etymology, takes us in two directions: what is not anyplace and an idealized/desired place. Utopia's location, then, is both nonexistent and impossible to determine because idealized. Insofar as idealized or imagined place, utopia does not refer to what is but to what could be. The category of heterotopia (Foucault, 1984) helped us to grapple with narratives on schooling and education in different ways. The word itself means, among other things, the presence or appearance of tissue or organs in places where they are not expected. As category, heterotopia enables us to grasp how juxtaposed narratives on schooling, on the subjects engaged in it and on the contexts in which they are produced, appear somewhere where they are not expected. Thus, heterotopias are 'off-places [...], places "outside"; locations on the edges or limits of the normal order of things' (Agier, 2012 , p. 490). Foucault (1984) proposes that, in all societies, there are utopias that can be located on a map, utopias with precise places and times, utopias that can pinpointed and measured. He goes on, 'it is highly probable that every human group [...] sets out in the space it occupies, where it really lives, where it works, places that are utopian and, in time, moments that are uchronic...' (Foucault, 1984, p. 20). Thus, in the intervened painting by the young people at the school, the composition of that place they occupy comes from the interplay between the critique of the conditions where their lives ensue and desire that never stops taking flight. And it is in that always taking flight that these other places appear, that these interconnected dreams burst out as so many dreams to then reconnect to the present, to critique the present, and to envision the very possibility of future and its conquest.

Utopia, like apocalypses, is often envisioned as solution, though there are many reasons, in contemporary society especially, to doubt that is the case. The narratives of future and of schooling we have examined here evidence these young people are not naïve; they have their feet on the ground and don't dream of tomorrows utterly beyond their reach. They think, rather, of tomorrows that are possible, of their future, of their school, and of their neighborhood. Only by being aware of how difficult the road ahead is can they construct, disenchantedly, some of their hopes.

The future today presents new and diverse dimensions and facets. On the one hand, it generates an array of fears and, on the other-given that man is a symbolic creature that cannot help but think about what is to come-it entails meaningful and interesting expectations, hopes, utopias, and even dystopias. In these narratives of the future, we come upon powerful ways of grappling with and envisioning education as future plan, as eyes looking at what will come, in a twofold operation that both takes root in the present and affords the possibility of imagining other futures. Thus, despite an atmosphere steeped in disenchantment, desires for change, for improvement, for better times to come and futures continue to circulate, sometimes in different wrappings, through schools today. If the writer is always of their time, if philosophy is territorialized in concept, desire arises in history to then escape it. In that sense, education can become the space from which to grapple with these times in and in response to them. A pedagogy of the concept (Deleuze \& Guattari, 2003; Peters, 2004) that takes root in the possibility of conceiving the world and destabilizing the future-worlding the word as key form of resisting the present.

\section{Notes}

1. The original work, painted by Ernesto de la Carcova in 1894, is an expression of political protest in Argentine and greater Latin American art. https://www.bellasartes.gob.ar/coleccion/obra/1777. The students worked on the basis of the painting in the framework of a project carried out in conjunction with the teachers at the school on the occasion of the painter's saint's day. The painter and his work are particularly relevant in this context because, due to a street in the neighborhood that bears his name, the area is known as La Carcova. The school and other community organizations took part in a show at a museum and at the university. See http://noticias.unsam.edu. ar/2016/11/16/se-realizo-el-festival-artistico-carcova-en-la-unsam/ 
2. Throughout the text, but especially in the opening pages, Rafael's resounding words formulate a criticism of what we would today call the incipient urbanization of the fifteen and sixteenth centuries and the problems it brought: "... the owners, as well as tenants, are turned out of their possessions by trick or by main force, or, being wearied out by ill usage, they are forced to sell them; by which means those miserable people, both men and women, married and unmarried, old and young, with their poor but numerous families (since country business requires many hands), are all forced to change their seats, not knowing whither to go; and they must sell, almost for nothing, their household stuff, which could not bring them much money, even though they might stay for a buyer. When that little money is at an end (for it will be soon spent), what is left for them to do but either to steal, and so to be hanged (God knows how justly!), or to go about and beg? and if they do this they are put in prison as idle vagabonds, while they would willingly work but can find none that will hire them" (More, 1989, p. 24).

3. This is not the place to address the populating and precarious or the lines and bifurcations of the colonial era. For a discussion of those topics, see Machado and Grinberg (2017).

\section{Disclosure statement}

No potential conflict of interest was reported by the authors.

\section{Notes on contributors}

Silvia M. Grinberg is researcher of the National Committee of Science and Technology in Argentina (CONICET), professor of Pedagogy (UNPA) and Sociology of Education. Director of the Center for Inequalities, subjectivity and Institutions (National University of San Martín, UNSAM). International invited scholar: UNAM (mexico), Universität Kassel (Germany); Universidad de Chile, Pontificia Universidad Católica de Chile (Chile); York University (Canada); Pontificia Universidad Bolivariana de Medellin, Pontificia Universidad Javeriana de Bogotá and Universidad de Santo Tomas, (Colombia); UNISINOS (Brasil); Institute of Education, University of London (UK); Université de Reims Champagne Ardenne (France).

Mercedes L. Machado, postdoctoral fellowship of the National Committee of Science and Technology in Argentina (CONICET), lecturer of Pedagogy (National University of San Martín, UNSAM).

\section{References}

Agier, M. (2012). El biopoder a prueba de sus formas sensibles, Política y Sociedad, Madrid Tomo. 49, N. 3 , $487-495$.

Aranbindoo, P. (2011). Rhetoric of the 'slum', city: Analysis of urban trends, culture, theory, policy, action. Routledge Taylor \& Francis Group, 15(6), 636-664.

Arendt, H. (1996). Between past and future. Eight exercises in political thought. Barcelona: Ediciones Península.

Augé, M. (2012). The Future. Buenos Aires: Adriana Hidalgo Editora.

Baugh, B. (2010). Experimentation, in, Parr (ed.) The Deleuze dictionary, Edinburgh: Edinburgh University Press.

BhaBha, H. (2002). The location of culture. Buenos aires: Manantial.

Bloch. (2004). The principle of hope (Vol. 1). Madrid: Editorial Trotta.

Butler, J. (2015). Notes towards a perfomative theory of assembly. London: Harvard University Press.

Cole, D. R., Dolphijn, R., \& Bradley, J. P. N. (2016). Fukushima:The geo-trauma of a futural wave. Trans-Humanities Journal, 9(3), 211-233.

Davis, T. (2010). Third spaces or heterotopias? Recreating and negotiating migrant identity using online spaces, BSA Publications, 44(4), 661-677. Retrieved from http://www.sagepub.co.uk/journalsPermissions.nav. doi:10.1177/003 8038510369356

Deleuze, G. (1986). Nietzsche and Philosophy. London: Continuum.

Deleuze, G. (1996). Crítica y clínica. Barcelona: Editorial Anagrama.

Deleuze, G., \& Guattari, F. (1983). Anti-Oedipus. Minneapolis: University of Minnesota Press.

Deleuze, G., \& Guattari, F. (2003). What is philosophy? London: Verso.

Deleuze, G., \& Guattari, F. (2005). A-thounsand-plateaus. Minneapolis/London: University of Minnesota Press.

Foucault, M. (1984). Of other spaces: Utopias and heterotopias (p. 5). Mouvement, Continuité: Architecture.

Freire, P. (2003). El grito manso. Buenos Aires. Siglo XXI.

Grinberg, S. (Ed.). (2008). Educación y poder en el siglo XXI. Gubernamentalidad y pedagogía en las sociedades de gerenciamiento. Buenos Aires: Miño y Dávila.

Grinberg, S. (2011). Territories of schooling and schooling territories in contexts of extreme urban poverty in Argentina: Between management and abjection. Emotion, Space and Society, 4(3), 160-171.

Haraway, D. (2015). Anthropocene, Capitalocene, Plantationocene, Chthulucene: Making Kin. Environmental Humanities, 6, 159-165. ISSN: 2201-1919. 
Lefebvre, H. (2002). Critique of Everyday Life. Vol. II. Foundations for a sociology of the everyday. (J. Moore, Trans.). London. Verso.

Lewis, S. L., \& Maslin, M. A. (2015, March 12). Defining the anthropocene. Nature, 519, 171-180. doi:10.1038/nature14258 Lyotard, J. (1984). The postmodern condition (1st ed.). Minneapolis: University of Minnesota Press, Print.

Machado, M., \& Grinberg, S. (2017). ¿La escolaridad como líneas de fuga? Educación, jóvenes y futuro en contextos de extrema pobreza urbana. Espacios en blanco. Serie indagaciones, 27(2), 231-252.

Magris, C. (2001). Utopía y desencanto. Historias, esperanzas e ilusiones de la modernidad. Barcelona: Editorial Anagrama. More, T. (1989). Utopia (Eds.), George \& Adams.

Peters, M. A. (2004). Geophilosophy, education and the pedagogy of the concept. Educational Philosophy and Theory, 36(3), 217-226.

Rose, N. (2007). The politics of life itself. Biomedicine, power, and subjectivity in the twenty-first century. USA: Princeton University Press.

Saez, V. (2015). Una mirada a la investigación sobre medios, violencia y escuela Entramado. Entramado, 11(1), 136-155. enero-junio. Colombia: Universidad Libre Cali.

Sirvent, M. (1999). Cultura Popular y Participacion Social. Miño y Dávila: Buenos Aires.

Tsing, A. (2017). Interview with Anna Tsing. suomen antropologi, 42(1), 22-30.

Tsing, A. (2018). Getting by in terrifying times. Dialogues in Human Geography, 8(1), 73-76. doi:10.1177/20438206177388 36journals.sagepub.com/home/dhg 